\title{
Forensic Science and Expert Testimony in Wrongful Convictions: A study of decision-making at the Criminal Cases Review Commission
}

\author{
Carolyn Hoyle \\ University of Oxford, UK
}

\section{Abstract}

The Criminal Cases Review Commission reviews possible wrongful convictions in England, Wales, and Northern Ireland, referring back to the Court of Appeal cases where there is a 'real possibility' that the conviction is unsafe. This article presents findings from a four-year empirical study of decision-making within the Commission. It explores how Commission staff exercise their discretionary powers in identifying and investigating possible wrongful convictions from approximately 1,400 applications a year, referring just a few back to the Court.

It focuses on a sample of cases that turned on forensic evidence and expert testimony, showing that while there is some variation in individual caseworkers' approaches to investigation, decision-making is shaped by the law and internal policies such that reasonably consistent decision frames emerge.

\author{
Keywords \\ Criminal Cases Review Commission, Court of Appeal, discretion, decision-making, forensic \\ science, expert evidence
}

\section{Introduction}

A quarter of a century ago, complacency about the reliability of police investigations and the safety of convictions was shaken by a series of 'catalytic cases' (Ashworth, 1998:11); unsafe convictions revealed in the years following the release of the Guildford Four in 1989, after 15 years' wrongful imprisonment. In 1991, a Royal Commission on Criminal Justice was announced on the day that the Court quashed the convictions of the Birmingham Six. Its report made 352 recommendations to increase the chances of the conviction of guilty persons and to reduce the risks of unsafe convictions through enhanced protections of suspects and increased powers for criminal justice agencies (Royal Commission on Criminal Justice, 1993). Ensuing academic research focused on the consequences of changes to the police and prosecution services (see Sanders et al., 2010 for a review of this literature). Less attention was paid to recommendation no. 331 to set up a new authority to correct possible miscarriages of justice. Article 8 of the Criminal Appeal Act 1995 brought about the establishment of the Criminal Cases Review Commission ('the Commission') for England, Wales and Northern Ireland in 1997. 
As the Commission celebrates its $21^{\text {st }}$ birthday, criminal justice is once again in crisis. The past few years have witnessed rising concern about damaging cuts to legal aid for defendants and appellants; police and prosecutors' failures to disclose potentially exculpatory evidence; and threats to the reliability of forensic science, which is increasingly relied on in criminal convictions. Injustice at pre-trial and trial stages increases the risk of wrongful convictions while cuts to the legal aid budget reduce the chances for those who seek relief in the appeal courts (Roberts, 2017:321). Meanwhile, the media has turned its critical gaze on the Commission, the body that must be relied upon to recognise and correct wrongful convictions.

On 30 May 2018 The Guardian reported claims by 'a group of prominent lawyers' that the Commission 'is not fit for purpose', accusing it of 'systemic failures', of not investigating cases thoroughly, of having become 'an office-bound, moribund organisation', and of referring too few cases $^{1}$; opinions that were aired in a television documentary on the same day. ${ }^{2}$ Such criticisms are not new. While in its first decade, it was thought to be an improvement on its predecessor (a small Home Office unit - C3) (Nobles and Schiff, 2001; Walker and McCartney, 2008), the past ten years has seen a growing concern among academics and practitioners that the organisation has not lived up to its potential (Nobles and Schiff, 2009; see various chapters in Naughton, 2009). In particular, the limiting nature and application of the test the Commission must apply before deciding to refer a case back to the Court of Appeal (the 'real possibility test'; see below) has been subject to wide-ranging critique (Newby, 2009; Naughton, 2009; Nobles and Schiff, 2009:158). Many criticisms levelled at the Commissionthough they may be prima facie compelling-have little or no empirical basis (Heaton, 2013:97). ${ }^{3}$ This article draws on data from the first major independent empirical assessment of decision-making and discretion within the Commission (Hoyle and Sato, 2018).

\section{The powers and limitations of the Criminal Cases Review Commission}

The Commission reviews possible wrongful convictions in England, Wales, and Northern Ireland, typically following the exhaustion of first instance appeals ${ }^{4}$, and refers back to the Court of Appeal ('the Court') ${ }^{5}$ cases in which it considers there to be a 'real possibility' that the Court will deem the conviction to be unsafe. In searching for fresh arguments or evidence, the Commission draws on approximately 30 case review managers ('caseworkers'), a legal advisor, an investigations advisor, about 12 commissioners (the

\footnotetext{
${ }^{1}$ The referral rate has reduced from 3.5 per cent in 2009/10 to 1.8 per cent in 2015/16 and 0.8 per cent in 2016/17, representing the referral of just 12 cases back to the Court of Appeal in the last year for which figures are available (Criminal Cases Review Commission, 2017a).

2 'Last Chance for Justice', Panorama, BBC, 30 May 2018.

${ }^{3}$ While there have been a few excellent empirical studies of the Commission, looking at specific issues (Heaton, 2013; Hodgson and Horne, 2009; O'Brian, 2011), most criticisms have no empirical foundation.

${ }^{4}$ An appeal should have been determined, or leave to appeal against it refused, before an application to the Commission (section 13(1)(c) Criminal Appeal Act 1995), though section 13(2) allows the Commission to review cases before direct appeal, and to make a reference 'if it appears to the Commission that there are exceptional circumstances which justify making it'. In practice, this happens in a significant minority of cases; see Hoyle and Sato, 2018, ch. 6.

${ }^{5}$ The jurisdiction of the Commission extends to the magistrates' court, for which a referral would be to the Crown Court, though most of its applications relate to convictions from the Crown Court.
} 
equivalent of eight full-time commissioners), and administrative and executive support (Criminal Cases Review Commission, 2017b:3).

Administrators prepare applications to the Commission by obtaining relevant supporting documents, such as court files, and by ensuring that the application is eligible for review; for example, that it falls within the statutory and geographical jurisdiction of the Commission. ${ }^{6}$ Applications are then subject to a relatively superficial review (what is referred to as 'screening') by commissioners and caseworkers that typically takes a few days or weeks. Following this, just under half are closed, with applicants sent a 'Statement of Reasons' for the Commission's decision not to investigate their case further and not to refer it to the Court. Remaining cases are allocated to caseworkers who conduct thorough investigations that may last months, and even years and could involve the commissioning of expert reports; interviews with applicants, witnesses and criminal justice professionals; and the collation of data from public and private bodies.

Caseworkers' investigations are supervised by commissioners who have the ultimate responsibility for referral decisions. While a caseworker will reach provisional decisions about the merits of the case, or the need for particular methods of investigation, most key decisions need to be approved by their assigned commissioner. The commissioner can make a unilateral decision not to refer a case back to the Court, though usually following advice from the caseworker, but a decision to refer can only be made by a committee of no fewer than three commissioners, after a thorough review of relevant case papers and a meeting to discuss the strength of the evidence and the grounds for a referral (Criminal Appeal Act 1995, sections 9-12). This clearly creates an institutional imperative to scrutinise more closely decisions to refer to the Court, than decisions to conclude a review without a referral.

To allow for rigorous investigations, the Criminal Appeal Act 1995 furnishes the Commission with various powers and responsibilities; it can require disclosure of evidence from public (article 17) and now private bodies (article 18a), ${ }^{7}$ instruct police forces to carry out investigations of cases prosecuted by other police forces (article 19), and it must carry out investigations for the Court when, for example, there is evidence of jury impropriety (article 15). The Commission is unable to quash convictions, having the power only to refer cases back to the Court if it is satisfied that there is a real possibility that the Court will quash the trial verdict; if, in other words, the case meets the 'real possibility test', as defined by Parliament (Criminal Appeal Act 1995, section 13(1)(a)). That said, the Court is obliged to hear any case the Commission refers.

As the Commission is required to consider how the Court will respond to a referral, its decision-making is inextricably tied to the test subsequently applied by the Court; is the conviction is 'unsafe'?; the Court does not need to be satisfied that the applicant is innocent. The evidence must be capable of belief, capable of forming a ground for allowing

\footnotetext{
${ }^{6}$ The Scottish Criminal Cases Commission reviews applications concerning convictions north of the border.

${ }^{7}$ Section 18a was added to the Criminal Appeal Act 1995 by the Criminal Cases Review Commission (Information) Act 2016.
} 
the appeal, and fresh (Criminal Appeal Act 1968, section 23). ${ }^{8}$ Case law has evolved on this latter issue such that a real possibility may be established when there are new arguments or evidence that have not previously been considered by the trial or appeal courts (Criminal Appeal Act 1995, section 13(1)(b)); see $R v$ Hickey, 1997). Furthermore, there must be a reasonable explanation for the failure to adduce the fresh evidence at trial if it had been available to the defence (section $2 \mathrm{~d}$ ).

Interpreting how persuasive fresh evidence or argument might be to the Court, the Commission needs to be mindful of the Court's response to past cases. Hence, the legislation has consigned the Commission to a somewhat subordinate role, ensuring deference to the Court's evolving approach to what constitutes an 'unsafe' guilty verdict and to the Court's changing notions of what kinds of evidence are acceptable. The Administrative Court ( $R v$ Criminal Cases Review Commission ex $p$ Pearson, 1999) and the House of Lords ( $R v$ Pendleton, 2001) have further made clear that the Commission must at all times be cognisant of the Court's decisions in previous similar cases, and that the Court, in turn, should consider what doubts the jury might have had if the trial court had been presented with the new evidence or argument.

Judgments and new legislation are regularly reviewed by the Commission and reproduced with analysis in Casework Guidance Notes, in Statements of Reasons prepared for applicants and the Court, and in informal communication between Commission staff. These are the routine ways in which the Commission guides its decision-makers' interpretations of evolving jurisprudence (Hawkins, 2002:50-51) and analysis of cases.

\section{An empirical study of the Criminal Cases Review Commission}

Given its limited resources, the Commission cannot conduct in-depth reviews of all of its approximately 1,400 applications a year and therefore operates a case screening process that produces a high rate of attrition. It subjects just over half of its applications to full and thorough investigation, rejecting the others with minimal review, and refers back to the Court only between one and four per cent of applications. ${ }^{9}$

There is considerable scope for discretion, for thorough examination of all possible avenues, or for choosing a more superficial consideration of the case. In deciding if there are reasons to doubt the safety of the conviction, and the particular grounds for a referral, the Commission may consider pre-trial procedural irregularities or ignored evidence; the case at trial; and any further evidence that has come to light since. It can commission forensic tests or call new expert witnesses and follow up new lines of enquiry. However, all investigations have one clear aim: to decide if the evidence meets the real possibility test.

This research subjects the application of the real possibility test to in-depth socio-legal analysis throughout the investigation and decision-making process from screening to the

\footnotetext{
${ }^{8}$ Under section 23 of the Criminal Appeal Act 1968, the Court can refuse to accept evidence that is not fresh, but has already been considered by the trial court or at a previous appeal, and evidence that is fresh but where there is no reasonable explanation as to why it was not adduced at trial.

${ }^{9}$ See note 1 .
} 
decision whether to refer cases to the Court, though here the focus is not on 'screening' (see Hoyle and Sato, 2018, ch. 6), but on those cases subjected to a full investigation. The research-carried out between 2011 and 2015-analysed the Commission's response to 146 cases (applications made since 2000) where the applicant claimed that they had been wrongfully convicted due to poor police investigation, non-disclosure of exculpatory evidence by the prosecution, poor legal representation at trial, unreliable witness testimony, and failures or lack of forensic and expert evidence. It also analysed cases where the Commission conducted investigations on behalf of the Court of Appeal and appointed external police forces to assist in investigations. In selecting cases to study, a purposive sampling method was adopted to identify categories of cases that would best illustrate the typical approaches to investigation within the Commission. These also represented most types of offences investigated by the Commission, the bulk of which are murder or sexual offences.

This article focuses on just one of these samples of cases: 61 applications where the main focus at trial and appeal was new forensic and expert evidence. This sample of forensic and expert evidence cases comprised primarily of convictions for the assault or killing of infants, other murders, rapes and sexual assaults. Twenty-five of these were referred back to the Court: in 19, new expert testimony was presented that undermined the evidence at trial (in just over half that testimony explicitly referred to advances in research or scientific consensus since the trial) and in a fifth of referrals new forensic science was the key referral ground. In order to understand decision-making, we had to over-sample referred cases, given that referral rates are so low, and therefore the reader should not generalize the likelihood of cases resulting in a referral from our sample of cases. ${ }^{10}$

For each case, we reviewed: the application; case record; case plan; the statement of reasons (a document outlining the justification for referring or deciding not to refer a case to the Court); correspondence with legal representatives, expert witnesses, the applicant, etc.; and internal correspondence and minutes of committee meetings. We conducted 90 interviews with current and former members of staff about cases and the working practices and culture of the Commission. In addition, we analysed all of the Commission's Casework Guidance Notes-internal policy guidelines that prescribe how individual commissioners and caseworkers should proceed at each stage in various different types of cases or situations - as well as Formal Memoranda on Commission practice. For each case we considered the extent to which the guidelines had shaped the casework approach and what other factors influenced decision-making. To ensure anonymity for applicants and their representatives, and Commission staff, ${ }^{11}$ we do not refer to applicants' names or other identifying features, even when their convictions have been quashed by the Court and information about their case is in the public domain.

\footnotetext{
${ }^{10}$ Our sampling approach did not allow us to compare referral rates across different types of cases and this would not have been possible by analysis of aggregate data as the Commission does not categorize its referral data according to the types of offences or the types of investigations.

${ }^{11}$ We received security clearance from the Ministry of Justice to gain access to case files (ref: 299962) and 'in house' Commission training on handling sensitive data. A confidentiality agreement between the University of Oxford and the Commission was required as well as approval by the University of Oxford's Research Ethics Committee (ref: SSD/CUREC1A/11- 235).
} 


\section{A socio-legal approach to understanding decision-making}

While conducting an initial 'scoping study', some Commission staff were adamant that to understand decision-making I need look no further than the legislation, case law, and the details of the case:

[W]e have to look at each case distinguished on its own facts, and obviously, we need to read what's coming out of the Court of Appeal so we understand their thinking [if] there's a real possibility. (\#74)

However, as Nelken (1998:407-8) reminds us, "legal actors often have little grasp of the factors which shape "inputs" and "outcomes" of their decisions'. Another interviewee explained, 'when you refer a case ... You try and decide it on its merits'.' (\#40) But Hawkins questions what it might mean to consider a case 'on its merits':

... although it is commonly said that decisions are made 'on their merits', a naturalistic approach takes the position that there is nothing self-evident or taken for granted about a decision, and that what is regarded as 'merited' is not only open to interpretation in each case, but only makes sense in the context of each decision (Hawkins, 2002:31).

Focusing on 'discretion as a quality of rules' (Lempert, 1992) is clearly to define the research terrain in unduly narrow terms.

Nearly half a century ago, Davis (1969:233) called for a new jurisprudence that would draw back from a narrow understanding of law to a wider appreciation of the various influences on discretionary decision-making. A positivistic approach that looks only at law would provide a partial picture of decision-making at the Commission. It would not allow for the sense-making and interpretation that inform decisions and that is evident in each and every case that has been analysed for this research. It permits no role for 'other forces that work upon a legal decision-maker compelling or constraining action which reside in matters normative, economic, political and organizational' (Hawkins, 1992a:18). Nor can it accommodate the influences of differences in experience, expertise or personality, which can inform decisionmaking. Instead, research should consider decision-making that works at both the individual and organizational level, with the latter having the potential to impose objectives and constraints upon those responsible for day-to-day decisions (Hawkins, 1992a).

That said, the law cannot be ignored. It is crucial to our understanding of why so few applications to the Commission are seen by the Court, given that the Commission is constrained by legislation and jurisprudence. As Lacey (1992) makes clear, different approaches to discretion from law and sociology are best considered together-or viewed as interdependent. Hawkins' naturalistic approach is receptive to both the legal and the sociological, considering discretion as the space . . . between legal rules where legal actors must exercise choice' (1992a:11).

The aim here is adopt a naturalistic socio-legal approach to understanding decision-making as an interpretive practice, identifying the 'conditions that lead to certain legally 
consequential outcomes (rather than others)' (Hawkins, 2002:30). In Law as Last Resort, Hawkins (2002; see also, 1992a, 2003) suggests that to understand the nature of discretionary decision-making, a connection ought to be made between a range of factors in the decisionmaking environment and the decision-making processes in which individuals engage. Hawkins' (2002) typology of 'surround', decision 'fields' and decision 'frames' allows this connection to be made and provides the theoretical framework for understanding discretion at the Commission:

Decisions about legal standards and their enforcement, like other legal decisions, are made, then, in a much broader setting (their 'surround') and within a context, or 'field', defined by the legal and organizational mandate. Decision 'frames', the interpretive and classificatory devices operating in particular instances, are influenced by both surround and field. (Hawkins, 2002:47-48)

\section{The influence of the surround}

Hawkins' notion of the surround refers to the social, economic, political and other environments which condition discretionary decision-making (2002:48-50). Surrounds are rarely unchanging, and a shifting landscape can impact on an organization, as it is forced or chooses to respond to external changes. Changes in the surround of the Commission have included evolving forensic science, evolving Court jurisprudence, and a dramatic rise in applications to the Commission alongside a reduction in their budget.

In our forensic and expert evidence cases, the Commission's work was clearly influenced by evolutions in the surround concerning scientific understanding and method. New forensic analysis included tests on biological samples (DNA), on fingerprints, on the likely causes of injuries to infants, and on firearms discharge residue or material fibres left at the scene of the crime or found on the suspect. In many such cases, the Commission responded directly to the changing surround of forensic evidence.

As an example, developments in the accuracy of DNA evidence assisted the applicant in case EE21, after it had become possible to extract a partial DNA profile from semen swabs stored since the trial. On account of this new DNA evidence, the Crown Prosecution Service informed the Commission that if minded to refer the case back to the Court, the Crown would not oppose the appeal, notwithstanding the defendant's guilty plea at trial (a factor that can militate against a referral; see Hoyle and Sato, 2018, ch. 6). The Commission was keen on an expeditious referral as the applicant had already spent over two decades in prison. Although the case committee acknowledged that the trial court had heard evidence that could not be refuted by new DNA evidence, it resolved to conduct no investigation of the case:

In the interests of expediting the matter, the Commission has conducted no analysis of the facts or law relating to [X's] case. It has based its decision [to refer] solely on the new DNA evidence which gave rise to the letter from the Crown Prosecution Service. (EE21, Statement of Reasons)

The Court quashed the conviction and the appellant was subsequently awarded compensation. 
News of the referral-and increasingly sophisticated DNA techniques of analysispersuaded the applicant in EE26c to submit a third application to the Commission in 2010 (following unsuccessful applications in 1998 and $2002^{12}$ ). His legal representative had already secured crime scene exhibits from the police and instructed a forensic scientist to analyse clothing for DNA. While there was other fresh evidence (from a neurosurgeon), DNA on the victim's clothing which did not originate from the applicant, but from another unknown male, provided the main ground for referral. The Court quashed the conviction, commending the Commission for its work, leaving it to reflect on why it had twice declined to refer this case (see Hoyle and Sato, 2018, ch. 13). Different caseworkers and commissioners in the previous applications had not considered the application sufficiently promising to conduct such investigations.

Though these two applicants eventually received justice, DNA alone is rarely enough to challenge a conviction. Most forensic tests are not conclusively exculpatory but must be interpreted by a range of experts who may not agree on their persuasiveness. In many of our cases, concerns were raised about how scientific data had been interpreted and presented at trial, leading to the commissioning of fresh expert evidence where the Commission was persuaded that it might assist their review:

[If] it's clear that the conviction was resting on a significant piece of forensic evidence, then that would drive [us]... to start doing a bit of research about that area; to ask, "Is that an area where there's been a shift in scientific opinion recently, and, if so, is that something that we need to explore further?" And as and when it's appropriate, we'll instruct experts. (\#26)

Following investigations, experts' reports are evaluated with a view to whether they undermine a conviction or merely present different, but equally plausible accounts of what might have taken place.

In 31 of our cases, expert opinion was commissioned to draw on advances in scientific knowledge, to challenge the original expert testimony, and sometimes to provide evidence not already tested at trial. For example, evolution in scientific understanding of what is 'normal' in children's genitals brought about significant change to the surround in the review of convictions for sexual abuse of children. Seven of our cases involving convictions for the rape and sexual assault of children were referred back to the Court, and convictions quashed, on the basis of new expert testimony following a report by the Royal College of Paediatrics and Child Health, 2008 ('RCPCH Report').

These trials had taken place in the late 1990s/early 2000s when there was consensus among medical experts that certain 'injuries' to children's genitals were indicative of sexual abuse. The RCPCH Report established that clinical findings which were considered to be representative of, consistent with, or probative of sexual abuse-for example 'attenuation' of a girl's hymen-are no longer necessarily regarded as such. New research demonstrated

\footnotetext{
12 If the Commission reaches a final decision not to refer a case, applicants can submit a new application (Criminal Cases Review Commission, 2013), with no limits on the number of times a person may re-apply.
} 
that such findings have been observed with comparative frequency in non-abused children, as they have with victims of abuse. As the caseworker in case EE11b noted:

In "modern money", what [the expert at trial] viewed as "inconclusive but suggestive", would now just be "inconclusive". What she viewed as "rare", will now be accepted as occurring naturally in a reasonable number of non-abused children (EE11b, Case Record).

The RCPCH Report also made clear what was required by way of rigorous scientific methods in examining children to produce reliable evidence (notably, pre-abuse examination evidence or examinations that include photographs or the involvement of a second medic), and some cases were considered to be unsafe because insufficient care had been taken.

Dr P, a consultant obstetrician gynaecologist and an $\mathrm{RCPCH}$ recognised 'Child Sexual Abuse expert', was commissioned to provide expert testimony on trial evidence in most of these cases. Because the RCPCH Report had not been published at the time of these trials, the Commission could present this fresh expert evidence as it could not have been relied on by the defence, thus avoiding the section 23 obstacle to a referral. ${ }^{13}$ In these cases, this expert stated that 'the way in which the medical evidence at trial was approached, expressed and interpreted was clearly defective' and would not meet with current professional guidelines (PI1, Statement of Reasons). As the Commission in case EE14c put it:

[expert witness'] opinion provides strong support for the contention that, contrary to the way in which the case was left to the jury, the medical evidence did not prove that the complainant had been sexually abused (EE14c Statement of Reasons).

In such cases, the Commission could conclude that 'the jury had been left with what is now clear as being misleading medical evidence' (PI1, Statement of Reasons).

While these cases were successful, the Commission soon learned that the RCPCH Report was not inevitably fatal to the safety of child sex abuse convictions. In case EE12, the Report and new expert witnesses were relied on to argue that the main prosecution witness had:

lacked key competencies and failed to comply with basic requirements in respect of notes, consistent use of terminology and conducting an examination....and if the jury had known this [and had the benefit of more recent expert evidence] the [trial] court may have acceded to the submission made by the defence as regards to "no case to answer", particularly bearing in mind [problems with the police interviews]. (EE12, Statement of Reasons)

Notwithstanding the fresh expert evidence and an attack on the credibility of one of the complainants, the Court upheld the conviction because the substance of the new expert witnesses' evidence did not 'introduce anything that has an important new bearing' on the case, and criticisms of the trial expert had already been considered by the jury at trial and 'dealt with in a full, fair and balanced summing-up'; they were not, in other words, new (EE12, Court judgment). ${ }^{14}$

\footnotetext{
${ }^{13}$ See Note 8.

${ }^{14}$ Case EE17, referred for very similar reasons, was also upheld by the Court.
} 
Hence, in reviewing cases, the Commission had to have one eye on the scientific expertise and another on evolving case law, and Case Records and Statements of Reasons in some reviews referred to the Court's reluctance to render a conviction unsafe just because the science has moved on:

The Commission is aware that the Court of Appeal has clearly indicated that the mere fact that the understanding of good practice has moved on since a conviction was investigated will not of itself render the conviction unsafe, not least because there is a need for finality in judgments. (EE19b, Statement of Reasons)

It became clear that while the RCPCH Report undermined the safety of these convictions, the Commission expected the Court to scrutinize the complainant's credibility and consider all other evidence-including other possible reasons for variations in a child's genitalsbefore concluding that convictions were unsafe. Following the first few unsuccessful referrals, the Commission revised its internal guidance, warning staff to be circumspect:

It seems clear that even where there is fresh medical evidence the Court of Appeal will generally scrutinise the complainant's credibility and consider all the evidence in the case in the round before concluding that a conviction is unsafe. It is not possible to discern any general principles, and future Commission references will need to be addressed on a case specific basis. (Criminal Cases Review Commission, 2011: para. 30)

Here we see the Commission responding to the changing surround by clarifying the decision field.

\section{The influence of the decision field}

The decision field refers to the defined setting in which decisions are made. It is, primarily, the law; including, statutes guiding the Commission's remit. However, as Hawkins (2002) notes, systems of formal rules, despite their appearance of precision and specificity, tend to operate in imprecise ways, leaving room for discretion. Hence the policies and guidance issued by the organization shape interpretation of the law and of relevant factors in the surround, thereby influencing decision-making. The field of the Commission comprises organizational imperatives found within Casework Guidance Notes and Formal Memoranda ('sets of ideas about how its ends are to be pursued'; Hawkins, 2002:50), which provide 'general guidance on ... sources you can approach for advice on certain things.' (\#29) In other words, the field is 'something defined by and acted on by the organization' (Hawkins, 2002:50). As such, the Commission's guidance aims to reduce variability in responses to cases. As one interviewee put it, 'the casework guidance, I think, means that we will, to some extent, have standardized our approach to certain things' (\#8)

The field is crucial to our understanding of decision-making. Caseworkers are not left to make sense of hundreds of pages of documents in each case with only the statutory guidance on the real possibility test. Decision-making is shaped by highly structured and detailed Casework Guidance Notes that are regularly revised in light of changing substantive law and jurisprudence. While they are not step-by-step manuals, internal policies provide much of the information needed to assist the caseworker and commissioner through reviewing an 
application. There are approximately 70 Casework Guidance Notes advising decision makers on when to interview applicants or witnesses, when and how to seek expert evidence, how to identify relevant issues, how to plan a review, how to organise a case committee, and how they should respond to guilty pleas, hearsay evidence, judicial review, and various other issues that can arise during and following an investigation.

In most forensic and expert evidence cases, Commission staff assessed the relative persuasiveness of the old and new evidence, taking account of evolutions in science, scientific method, and interpretation of data. The predictive nature of the real possibility test means that the Commission needs to be mindful of the evolving Court jurisprudence and to reflect that in its internal policies. If it is thought that fresh expert evidence is not sufficiently different from that presented at trial, that it cannot challenge the prosecution case, or that the new expert evidence was known at trial, but a tactical decision was made by the defence not to use it, the Commission may be reluctant to refer the case.

Emerson and Paley's (1992) analogy of the 'organizational horizon' shows how organizations provide a framework to condition the way discretionary decisions are made. Within these organizational horizons, decision-makers are expected to have a working knowledge of how other cases of the same nature would be approached, as well as the implications of allowing the case to proceed to the next stage of the relevant administrative or bureaucratic process. Hence, while case law is part of the surround-and so beyond the control of the Commission-once the Commission deliberates on those cases in its formal guidance, case law becomes an integral part of the decision field. Our data provided many examples of decisions which explicitly referenced and drew on decision-making processes in other similar cases.

In some cases, the Commission explicitly looked for a precedent, with decisions about referral deferred until similar cases had been decided by the Court. For example, having investigated all available evidence in case EE15, the caseworker recorded: 'In essence, I am unpersuaded that the new evidence which nullifies the medical evidence is such as to raise a real possibility. I propose to write this up as a non-referral' (EE15, Case Record). The supervising commissioner suggested the case merited consideration by a committee, but before the committee had met, the case was put 'on hold' pending judgment in a similar case before the Court. Emboldened by the Court's decision to quash the conviction in the comparator case, case EE15 went to committee, where it was decided that there was sufficient evidence to refer.

Similarly, in deciding to refer case EE14c, where 'new medical evidence suggested that the evidence relied on at trial was flawed' (EE14c, Statement of Reasons), the Commission had compared the case to EE11b, which had been quashed by the Court, arguing that case EE14c was 'a stronger case' and therefore would likely succeed. However, this approach is not always effective: when the Commission referred case EE17, it brought the Court's attention to its response to similar recent cases:

The Commission notes that the Court of Appeal has quashed convictions in a series of cases where experts at trial had diagnosed abuse by relying on physical signs found during examination. Subsequent developments in medical knowledge have shown the same signs 
to be neutral and so incapable of supporting allegations of sexual abuse. The Commission has itself referred some of those cases to the Court of Appeal. (EE17, Statement of Reasons)

Notwithstanding the similarities in the cases, the Court upheld the conviction.

Internal guidance puts considerable focus on the question of how persuasive the Court will find new expert witnesses and makes clear that in general the Court regards experts as being 'interchangeable'. In the oft cited case of $R v$ Stephen Jones, 1997 the Court clarified the application of section 23 in cases that present new expert testimony, warning against the presentation of better expert witnesses at appeal whose evidence could have been given at trial. Indeed, in certain cases (e.g. $R v$ Pendleton, 2000), the Court has reminded the Commission that the criminal justice system does not allow two trials; one by jury with one team of lawyers and the second, some years later, in the Court of Appeal after a new expert has been found to say something different to the one at trial.

When determining whether the Court is likely to receive the evidence, the Commission should also be mindful of suggesting that a new expert is superior to the person who had given evidence at trial. Internal guidance reminds decision makers to be wary of the dangers of presenting 'bigger and better' experts, referring specifically to $R v$ Horton (2007), to show that applicants do not have a right to jettison evidence of an apparently eminent and conscientious expert to search for another who might prove favourable to the defence. The Court in this case not only made clear what it would reject, but enunciated situations where obtaining fresh expert evidence would be justifiable, including a developing area of science, where significant pieces of evidence had been withheld, overlooked or misunderstood, or following a blatant misdiagnosis. The Statement of Reasons in case EE12, reflects on this distinction: 'it will not generally be open to an appellant, without very good reason, to seek to call on appeal a "bigger and better expert" than was called at trial', but goes on to draw on $R v$ Steven Jones to establish that it would be allowed 'if it was expedient, necessary, and in the interests of justice'.

In most of the child sexual offence cases in our sample, the Commission relied on the same new expert witness, a Dr P, a 'bigger and better' expert than those who had given testimony at trial, and so it needed to consider if the Court would accept this new evidence. In most, it argued that it was not just presenting a 'different expert providing a different opinion, but rather the enunciation of a substantial altering of scientific understanding' (EE15, Statement of Reasons).

Cases were more likely to be referred when the Commission had additional exculpatory evidence to present alongside their 'bigger and better expert'. Hence in case EE29, while the Commission noted that 'the Court doesn't like when a number of experts are approached and discarded until a favourable opinion is obtained', this case was thought to be different as developments had been made in this area since the applicant's trial 'so it's not just experts rehashing the same methodology' (EE29, Case Record).

Clearly the Commission's task is to establish that the expert testimony at trial was so flawed that the case may be unsafe and to find new scientific evidence or expertise, that could not have been presented at trial, and that the Court might think sufficiently strong to have 
persuaded the jury to acquit the defendant if it had been presented. Only in such cases does the Commission have a chance of getting past the Court's reluctance to disturb a jury's verdict. However, while the field can guide this pursuit of evidence and expertise, and shape decisions, it leaves some discretion for deciding when a case is sufficiently strong or when an applicant's account is persuasive. Hawkins' notion of decision 'framing' helps us to understand how different people might come to different conclusions on this.

\section{Decision framing}

For Hawkins (2002), how the law is conceptualized in a given situation depends in large part on the framing practices of individual decision-makers. Hence, the 'real possibility test' could be applied differently given shifting understandings of how persuasive certain evidence might be in a particular context at a particular time. A frame is a structure of knowledge, experience, values, and meanings that Commission staff employ in deciding how to organize the content of applications and make sense of the evidence throughout the review process. It addresses the question 'What is going on here?' (Hawkins, 2002:52). The facts of the case are not synonymous with the frame; the frame is applied to a case in order to identify the 'relevant' or 'helpful' facts and discard those that do not help the decision-maker's analysis. At the same time, as 'facts and frames are reflexive' (Hawkins, 2002:53); facts can narrow the potential frame.

Frames are influenced by the culture of the organization but also by individual biographies. The culture of the Commission emerged from our analysis of its responses to applications as well as from interviews with staff and observations throughout years of fieldwork. It is a somewhat risk-averse, careful, thorough organisation that is diffident with the Court. That said, the culture of the organisation is not static. It has recently changed, in response to criticisms and to the pressure of reduced budgets and an increased caseload, becoming a more efficient organisation (see Hoyle and Sato, 2018, ch.12).

While the culture of the organisation shapes working rules and assumptions, there remain differences among individual staff. Hence, a commissioner with a prosecution background might interpret an application through a somewhat different frame to a commissioner from a civil service or a regulatory background:

Commissioners ... are very individual. And when you get to meet them and to work with them, you very quickly see the threads from where they've come from. [X] comes from a defence solicitor background, you see that in the way that they approach work ... very keen to get hold of defence papers, very keen to look at issues where an applicant might be criticising the police. [Y] is [an experienced barrister], and the way in which they work, clearly used to being able to delegate work to people, not have to necessarily do all the groundwork themselves, but wants to read absolutely everything, so that they know that case inside out, and nothing's missed ... And you see that through each of them. (\#26)

Individual decision-makers' understandings of their own, and their colleagues' discretionary behaviour provide insights relating to 'operational ideologies', 'frames of relevance' or 'assumptive worlds': essentially, value systems which allow individuals to make sense of and impose explanations on the settings in which they work (Lacey 1992:383). For example, one 
of our interviewees, a caseworker with many years of experience working with commissioners, explained:

[D]ifferent commissioners have different styles. [X] likes to read it and agree it [instantly]. $[Y]$ likes to read it and maybe have a meeting and to make lots of amendments. [Z] likes to have a meeting just to make sure he's clear the basis of the decision that he's making. But it's different styles... (\#5)

Similarly, different framing behaviour will likely influence distinct approaches from legal advisors, investigations advisors (who tend to be from policing backgrounds), and even throughout hierarchical structures - with young, inexperienced caseworkers likely to adopt different frames to established commissioners.

Individual caseworkers' experience, cognitive styles, and preferences will inevitably influence the manner in which information is sought, processed, and utilized (Choo, 2006:46). Experience, occupational background, personalities, and even variations in tenacity can influence case review:

There are definitely natural tendencies of those sorts, and every variance in between. ... So, in case discussions, you know someone's inclined to keep going, keep going. Perhaps you might challenge that a bit more, try and draw them back, where that's appropriate. And with other people who are perhaps inclined to think "No, load of nonsense. Not doing anything more, that's the end of it", then you might be trying to challenge a bit more and say, "What about this, what about that, what about so and so?" (\#26)

[I] worked out that, actually, you don't need to know everything about a case in order to be able to review it. ... Whereas, I think a lot of other caseworkers ... do an almost kind of bottom-up style review, whereby they feel they need to know every single thing about a case. (\#63)

It takes confidence to know when there is sufficient information for a decision, or to persuade a group of peers that an initial decision is valid. Cautious decision-makers might require more data before a decision is made, while the more confident may feel able to make a decision with less information or with equivocal data. Clearly, information needs should be understood both in terms of a decision-maker's cognitive needs (gaps or deficiencies in their understanding or knowledge) and in terms of their affective or emotional needs.

Lack of information impacts on people differently. For some, uncertainty will create apprehension, causing them to seek ever larger amounts of information, while others suffer greater arousal at information overload (Choo, 2006). Consequently, some caseworkers may seek data that closes down the possibilities in the case, whereas others may explore more and ever varied sources. The risk with the former is that a decision is made prematurely without all available relevant information. In a handful of our cases, we witnessed such an approach and subsequent reapplications led to referrals after different teams reviewed the material, did further investigations and found reasons to doubt the safety of convictions. The risk with anxious caseworkers who seek ever increasing amounts of data is that an investigation takes many more months or years than might be necessary, causing distress to 
the applicant and impacting on resources at the Commission. We had a few such cases in our sample. One somewhat fretful caseworker took years assessing the mounting evidence before it was decided not to refer the case; a decision that seemed surprising. An interviewee referred to such caseworkers 'getting enthusiasms about cases and just going away on endless frolics', adding that some commissioners too are:

slightly too inclined to want to commission yet further work, because they're reluctant to take a decision until they've explored every avenue ... [It] is sometimes a pretext for...conscious or subconscious, for putting off the decision-making day. (\#9)

As the real possibility test requires decision-makers to judge if, and when, the evidence is sufficient to refer a conviction back to the Court, in all cases at various stages of the review, decision-makers employ a legal decision frame, a mechanism for defining certain facts as legally relevant, as having 'the potential for authoritative consequences' (Hawkins, 2002:57). However, in many, if not most cases, the data are equivocal and challenges to decision frames, from within the Commission, but also from the applicant and their legal representative, can help staff to manage ambiguity in their investigations. Analysis of decision-making in forensic and expert evidence cases suggests another decision frame that helps decision makers to manage ambiguity; the narrative frame. This typically works alongside the legal frame but is informed by the 'stories' that unfold from analysis of cases and that make some cases more plausible than others.

Our analysis shows that decision-makers can be ambivalent about whether new forensic tests or new expert evidence are sufficiently robust. Case records demonstrate uncertainty when the evidence is ambiguous and show that at any one time it may not be clear whether the investigation will end in a referral or not. In case EE34, for example, the Case Record includes extensive notes by the commissioner which read like a deliberation on the pros and cons of the applicant's case. The caseworker was asked to prepare a report for the committee 'that could be written up either as a referral or as a refusal, as long as the issues are laid out before the committee' (EE34, Case Record), not an uncommon request. The record made clear that the caseworker preferred the option of a referral, but following deliberation, the committee decided that it was not minded to refer and asked the caseworker to edit the statement of reasons so that it justified this decision.

This equivocation was a feature of other complex cases. In case EE17, the caseworker was initially persuaded not to refer, believing that the evidence was not sufficiently strong. A draft Statement of Reasons was shown to the commissioner to see if it should be signed off or if it needed to be agreed by a case committee. The commissioner was not only inclined to take it to committee but asked the caseworker to re-draft the Statement of Reasons so that it recommended referral and to 'reverse the analysis and reasons ... which are not referable and promote' the expert evidence that could provide grounds for a referral (EE17, Case Record). Who is to say who was 'right' in this case? The committee agreed to refer the case, but the Court upheld the conviction, suggesting the caseworker's reticence may have reflected a clearer understanding of the case. However, who was 'right' is not really the point. These examples show that at any one time it is not entirely clear which direction a case will go, that different people throughout the review assess the evidence differently and 
their influence will shape the way the case is constructed. Quite clearly, the legal facts do not always speak for themselves; they must be interpreted through decision frames.

Without a smoking gun, produced early in a review, uncertainty can lead to the commissioning of further expert testimony until there seems to be a preponderance of evidence pointing in one direction. This may produce the requisite evidence to satisfy the legal frame (such as new expert testimony on the forensic evidence presented to the jury, as we saw above in relation to child sexual abuse cases) or a reason why new evidence could not have been adduced by the defence at trial (related, for example, to a witness who has proven to be unreliable since the trial). However, the process of sense-making (Choo, 2006) is more often driven by plausibility and persuasiveness, than pursuit of a truth. The Commission must decide if, considering all evidence now available, the jury would likely have found the applicant's account sufficiently persuasive, or, more precisely, if the Court would be liable to believe that the jury would have been persuaded.

When it is not clear if new forensic or expert evidence could satisfy the real possibility test, Commission staff sometimes turn to a narrative decision frame; they select a plausible meaning from possibly several alternative meanings to make sense of past events about which they inevitably have only partial information. When there are competing expert testimonies, both concerning evidence presented at trial and new expert evidence, they must judge which is the most persuasive. In making these decisions, they try to shape a plausible narrative out of the sometimes-disparate evidence at hand. This can be hard if the applicant cannot provide a credible alternative explanation to that presented by the prosecution. For example, the applicant in case EE4 had consistently denied doing anything harmful to the child in his care but could provide no plausible (innocent) narrative as to what may have caused the child's death.

Such reviews often look beyond the insufficiently robust forensic and expert testimony to 'the consistency and credibility (or otherwise) of the defendant's story, the defendant's record ... etc.' (EE5, Case Record). The applicant in case EE1 had been convicted of the murder of two infants. New expert evidence on the erroneous nature of the trial expert's statistics on probabilities of 'cot death' had already been presented to the Court on direct appeal, leaving the Commission searching for 'fresh' evidence. Subsequent to further medical investigations, the Commission's reference back to the Court focused on microbiological tests as providing plausible explanation for a natural cause of death, and the Court duly quashed the conviction. The Statement of Reasons referred to: 'the overwhelming significance' of the new information about an infection, but the Case Record shows that the emerging plausible narrative was assisted by other review findings and perceptions that pointed to the truthfulness and credibility of the applicant. For example, the Crown had suggested that 'lies' told by the defendant and the other parent at the time of the second death had cast significant suspicion on the defendant, whereas the Commission decided that there was a perfectly reasonable story for the shifting account of events. Members of the case committee are recorded as spending some time dealing with the question of the veracity of the applicant's account and creating a narrative that 
portrayed inconsistencies as 'explicable' in light of the traumatic events that had unfolded. ${ }^{15}$ The Case Record also reports significant media interest in this case, and the first sentence of the Statement of Reasons refers to the professional status and previous good character of the applicant.

Conversely, the applicant in case EE16, convicted for indecent assault of a child, had explained the injuries to the child's genitals by reference to a sporting accident. Following a thorough review, the Commission concluded that the accident had been too minor to have caused any significant injury and consequently the research published in the RCPCH Report was inapplicable. This applicant's credibility was questioned, with the Case Record noting that 'we are also puzzled by [the applicant's] silence in interview'.

Clearly, the narrative frame does not compete with the legal frame. A good story cannot compensate for unconvincing forensic evidence that will not satisfy the real possibility test. However, often evidence is contested, suggestive of various conceivable accounts, and in such cases the narrative frame may help the Commission to present to the Court a plausible account of what might have happened, particularly if the applicant appears to be credible.

\section{Conclusion}

Analysis of the Commission's response to cases that turn on forensic and expert evidence demonstrates the interconnectedness of the surround, the field, and the decision frame. Within the decision frame, neither the surround nor the field recede to the periphery, both are actively drawn on as the decision maker makes sense of the case before them (Hawkins, 2002). Expert evidence investigations often collate considerable, sometimes impenetrable data that can remain tentative or contested. With each case somewhat unique, it should not be surprising that uncertainty can result in variability in interpretation of the real possibility test. That said, we identified more consistency in applying legal and narrative decision frames than we expected.

By understanding decision-makers' 'framing behaviour', we found that discretionary outcomes at the Commission are, in fact, patterned, guided by shared systems of meaning, tacit understandings of the 'surround', organizational routines, and mutually agreed ways of arriving at a decision, as presented in internal policies (Cotterrell, 1998:178). Hence while we saw some differences in framing behavior, and different approaches to interpreting evidence across many cases, distinct patterns of interpretation emerged. These were the product not of positivist approaches, or of caseworkers blindly following rules within their 'field', but of shared understandings, routines, and working rules, and of a shared surround and a highly structured decision field.

The Court's evolving jurisprudence-a key feature of the Commission's surround-directly impacts on the decision field, which thereafter influences decision frames. The legislative predictive nexus of the 'real possibility test' inevitably locks the Commission into a close,

\footnotetext{
${ }^{15}$ The Case Record contained other evidence of commitment to a plausible (innocent) narrative but further information on this could risk breaching our anonymity agreement with the Commission.
} 
deferential relationship with the Court, leading friends and critics of the Commission to worry about it being overly submissive (Elks, 2008:77). Caseworkers and commissioners sometimes await Court judgments in similar cases, or cases that raise analogous issues, before deciding whether new evidence is likely to be seen by the Court to significantly improve on the expert case at trial. In light of those cases, they decide whether to refer and, if so, on what grounds. Thus, when the Court shifts its interpretation of safety, the Commission follows suit, typically disinclined to push back, particularly if it cannot dismantle the bulk of the prosecution case. This could be interpreted as deference or pragmatism (learning from past judgments to identify evidence that is likely to be accepted by the Court, and to play down factors that have not proven to be persuasive in the past) and, of course, if the Court gets it right, the Commission does too. However, if the Court gets it wrong, if it is too restrictive in its interpretation of its own legislation, this approach affords no opportunities for the Commission to correct that.

This study focused on decision making at the Commission, not the Court, but interviews with Commission staff demonstrated an increasing concern that the Court was becoming more reluctant to quash convictions based on fresh evidence. They were not surprised when Stephanie Roberts' new research showed that while the number of appeals based on fresh evidence had almost doubled since a similar study by Malleson (1993) in 1990, the rate at which the Court had admitted that fresh evidence had declined significantly from 61 per cent in 1990 to 19 per cent in 2016 (Roberts, 2017). Given that the Commission's decision field and frames are strongly shaped by evolving jurisprudence, and that commissioners perceive the Court to be less impressed by fresh expert and forensic evidence, its decisions may become more conservative, causing it to refer even fewer cases, and some wrongfully convicted people will remain in prison.

The Commission is somewhat deferential to the Court because legislation has made it so. Those who criticize the real possibility test could be criticizing the safety test of the Court. If the Commission was prepared to push at the boundaries of the real possibility test, and make bolder, sometimes 'contrarian' referrals, and if the Court could be persuaded by these bolder referrals to be more receptive to fresh evidence, ${ }^{16}$ and less deferential to the jury and the principle of finality, there would likely be fewer critics of the real possibility test. Given the currently decreasing referral rate, this might be a good time for the Commission to adopt a bolder approach to referrals, to try to shift the Court's jurisprudence, though the obvious risk would be of a lower overall success rate. Some Commission staff worried that pursuing borderline cases would cause reputational damage to the Commission, and raise, only to dash applicants' expectations:

You should be slow to challenge the decision of the jury if it was made on full facts... You need something that really is genuinely new and powerful ... [and if my] experience tells me that this simply will not get through, then, in those circumstances, I think it is unfair to the applicant to refer, . . . to be making a stand. (\#36)

Others, though, felt differently: 'I think we could be bolder ... there are cut-and-dried cases, and there's a grey area. And I think in the grey area, we ought to lean more towards referring.' (\#25) It is unlikely that the Court would uphold all such 'borderline' convictions,

\footnotetext{
${ }^{16}$ See Note 8.
} 
but even if it did, the process of referring such cases, and having them aired in Court, would at the very least expose systemic failings in the criminal justice system. At a time of rising concern about prosecution failures to disclose potentially exculpatory evidence and inadequate legal defence in a system damaged by austerity measures, this would surely be beneficial.

\section{Funding}

This work was supported by the Leverhulme Trust [RPG-2013-170]; and the University of Oxford John Fell Fund [103/926 2011 \& 122/684 2013].

\section{Acknowledgments}

The author is grateful to Dr Mai Sato who provided research assistance during 2013-15.

\section{Declaration of Conflicting Interests}

The author declared no potential conflict of interest with respect to the research, authorship and/ or publication of this article.

\section{References}

Ashworth, A. (1998) The Criminal Process. 2nd edn. Oxford: Oxford University Press.

Choo, CW. (2006) The Knowing Organization: How Organizations Use Information to Construct Meaning, Create Knowledge, and Make Decisions. 2nd edn New York: Oxford University Press.

Cotterrell, R. (1998) Why Must Legal Ideas Be Interpreted Sociologically? Journal of Law and Society 25(2):171-92.

Criminal Cases Review Commission (2011) Casework Guidance Note Decision-Making Committees.

Criminal Cases Review Commission (2013) Formal Memorandum Stage 1 Decisions.

Criminal Cases Review Commission (2017a) Annual Report and Accounts 2016/17.

Criminal Cases Review Commission (2017b) Business Plan 2016/2017.

Davis, K.C. (1969) Discretionary Justice: A Preliminary Enquiry. Baton Rouge: Louisiana State University Press.

Elks, L. (2008) Righting Miscarriages of Justice? Ten Years of the Criminal Cases Review Commission. London: JUSTICE. 
Emerson, R.M. and Paley, B. (1992) Organizational Horizons and Complaint-Filing. In Hawkins K (ed) The Uses of Discretion, Oxford: Oxford University Press, pp. 231-48.

Hawkins, K. (1992a) The Use of Legal Discretion: Perspectives from Law and Social Science. In Hawkins K (ed) The Uses of Discretion. Oxford: Oxford University Press, pp.11-46.

Hawkins, K. (2002) Law as Last Resort: Prosecution Decision-Making in a Regulatory Agency. Oxford: Oxford University Press.

Hawkins, K. (2003) Order, Rationality and Silence: Some Reflections on Criminal Justice Decision-Making. In Gelsthorpe E and Padfield N (eds) Exercising Discretion: DecisionMaking in the Criminal Justice System and Beyond. Cullompton: Willan, pp.186-219.

Heaton, S. (2013) A Critical Evaluation of the Utility of Using Innocence as a Criterion in the Post-Conviction Process. PhD Thesis, University of East Anglia, UK.

Hodgson, J. and Horne, J. (2009) The Extent and Impact of Legal Representation on Applications to the Criminal Cases Review Commission (CCRC): A Report Prepared Fo the Legal Services Commission. Retrieved (https://papers.ssrn.com/sol3/papers.cfm?abstract id=1483721).

Hoyle, C. and Sato, M. (2019, forthcoming) Reasons to Doubt: Wrongful Convictions and the Criminal Cases Review Commission, Oxford: Oxford University Press.

Lacey, N. (1992) The Jurisprudence of Discretion: Escaping the Legal Paradigm. In Hawkins K (ed) The Uses of Discretion, Oxford: Oxford University Press, pp.361-88.

Lempert, R.O. (1992) Discretion in a Behavioral Perspective: The Case of a Public Housing Eviction Board. In Hawkins K (ed) The Uses of Discretion. Oxford: Oxford University Press, pp.185-230.

Malleson, K. (1993) 'Review of the Appeal Process, RCCJ Research Study No 17'. London: HMSO.

Naughton, M. (ed) (2009) The Criminal Cases Review Commission: Hope for the Innocent? Basingstoke: Palgrave Macmillan.

Nelken, D. (1998) Blind Insights? The Limits of a Reflexive Sociology of Law. Journal of Law and Society 25(3):407-26.

Newby, M. (2009) Historical Abuse Cases: Why They Expose the Inadequacy of the Real Possibility Test. In Naughton M (ed) The Criminal Cases Review Commission: Hope for the Innocent? Basingstoke: Palgrave Macmillan, pp.97-106.

Nobles, R. and Schiff, D. (2001) The Criminal Cases Review Commission: Reporting Success? The Modern Law Review 64(2):280-99. 
Nobles, R. and Schiff, D. (2000) After Ten Years: An Investment in Justice? In Naughton, M (ed) The Criminal Cases Review Commission: Hope for the Innocent? Basingstoke: Palgrave Macmillan, pp.151-65.

O’Brian, W.E. (2011) Fresh Expert Evidence in CCRC Cases. King's Law Journal 22(1):1-26.

Roberts, S. (2017) Fresh Evidence and Factual Innocence in the Criminal Division of the Court of Appeal. The Journal of Criminal Law 81(4):303-27.

Royal Commission on Criminal Justice (1993) Report (Cm 2263). London.

Sanders, A., Young, R. and Burton, M. (2010) Criminal Justice. 4th ed. Oxford: Oxford University Press.

Walker, C. and McCartney, C. (2008) Criminal Justice and Miscarriages of Justice in England and Wales. In Huff, RC and Killias M (eds) Wrongful Conviction: International Perspectives on Miscarriages of Justice, Philadelphia: Temple University Press.

\section{Cases}

$R v$ Criminal Cases Review Commission ex p Pearson [1999] 3 All ER 498.

$R v$ Hickey [1997] EWCA Crim. 2028.

$R v$ Horton [2007] EWCA Crim 607.

$R v$ Pendleton [2000] EWCA Crim 45 [2001] UKHL 66 [2002] 1 WLR 72 (HL).

$R v$ Steven Jones [1997] 1 Cr App R 86. 